\title{
An Open and Diverse European Union?
}

\author{
Nuna Zekic \\ Assistant Professor in Labor Law, Department of Social Law and Social Policy, \\ Tilburg University, Tilburg, The Netherlands \\ n.zekic@tilburguniversity.edu
}

\begin{abstract}
People have the right to manifest their religion or belief. They also have the right not to be discriminated against because of their religion or belief. In addition, most people need employment to provide in their livelihood. It was already known that freedom of religion can be restricted in the employment in the public sector. The public sector (i.e. the government) needs to be able to project neutrality also through its employees. However, the Court of Justice of the European Union expanded this possibility of rights restriction to the private sector. This decision has the potential to harm the chances of obtaining employment of certain minorities in Europe.
\end{abstract}

\section{Keywords}

employment - discrimination - religion

\section{Introduction}

One of professor De Sousa Santos' main points in the Montesquieu Lecture is that 'Europe is becoming intercultural'; he suggests as a 'way forward' that we 'affirm this interculturality' and not deny it or go against it. Sadly, we see too much of the latter happening, even in law. Another important remark concerns the growing power of the market over the state and the community, and sadly, the law is only endorsing this power of the market. A clear manifestation of these two observations can be found in two judgments by the Court of Justice of the European Union (CJEU) issued just two days before this lecture. These two long-awaited judgments concern the manifestation of beliefs in

(C) NUNA ZEKIC, 2017 | DOI 10.1163/22112596-02201012

This is an open access article distributed under the terms of the prevailing CC-BY-NC license at the time of publication. 
the private workplace. ${ }^{1}$ In both cases, the employer - a private company - dismissed a female employee, because she refused to remove her headscarf. In the Belgian case, Achbita v. G4S Secure Solutions NV (Achbita case), the dismissal was based on a workplace regulation, which was enacted after Ms Achbita had informed her manager that she intended to wear an Islamic headscarf during working hours. According to this internal rule, employees were prohibited from wearing any visible signs of their political, philosophical or religious beliefs in the workplace, as wearing such signs would infringe company's 'neutrality policy'. In the French case, Bougnaoui v. Micropole sA (Bougnaoui case), Ms. Bougnaoui was already wearing the headscarf when she was hired as an engineer. After complaints of customers, she was fired when she refused to remove it. There was no (written) workplace regulation with a 'neutrality policy' at this company.

2

\section{Neutrality Policy}

In the Achbita case, the Court found there was no direct discrimination at stake, because the internal rule at issue 'refers to the wearing of visible signs of political, philosophical or religious beliefs and therefore covers any manifestation of such beliefs without distinction. The rule must, therefore, be regarded as treating all workers of the undertaking in the same way by requiring them, in a general and undifferentiated way, inter alia, to dress neutrally, which precludes the wearing of such signs.' ${ }^{2}$

At first glance, this may seem fair: the company has a neutrality policy and it asks all employees to dress neutrally. Moreover, it precludes visible signs of any political, philosophical or religious belief. However, does this mean that all workers are treated in the same way, as the Court says? Actually, this is not the case. Some employees can meet the target of 'dressing neutrally' much easier than other employees. Secular employees are much less affected by such rules, than religious employees are for example. In fact, to 'dress neutrally' has a quite specific meaning in this context. In spite of what is considered 'appropriate wardrobe' varies by workplace, it is apparent that in this context dressing

1 C-157/15 Achbitav G4S Secure Solutions [2017] CJEU; C-188/15, Bougnaouiv Micropole SA [2017] CJEU.

Both cases are analysed by the Court in the context of the Council Directive 2000/78/EC of 27 November 2000 establishing a general framework for equal treatment in employment and occupation concerning the grounds of religion or belief, disability, age or sexual orientation.

2 C-157/15 Achbita v G4S Secure Solutions [2017] CJEU, Para 30. 
neutrally means dressing in a way that falls within the boundaries Western fashion dictates. People who do not wish to dress in that specific way - may it be because of their religious, political or philosophical belief, or simply because of a different descent or tradition - face a less favorable treatment when such an appearance is the rule. These people - minorities in Europe - need to adapt their appearance in a way that may seriously conflict with their (religious) belief or tradition in order to either obtain or hold their job with an employer that has a neutrality policy in place. By such rules, they are treated less favorably than the majority of the people in Europe who do not have to make such adaptions to their appearance.

Direct discrimination occurs when one person is treated less favorably than another person in a comparable situation on account of religion or belief, disability, age or sexual orientation. ${ }^{3}$ In the past, the CJEU has adopted a general understanding of the concept of direct discrimination. ${ }^{4}$ However, it does not assume there is direct discrimination in the Achbita case, ${ }^{5}$ even though the wording of the company rule at stake is directly linked to religion.

One might object here that the 'less favorable treatment' I am pointing out may be directly linked to religion, but not to one particular religion and not to religion only. Advocate General in the Achbita case argued: 'That requirement of neutrality affects a religious employee in exactly the same way that it affects a confirmed atheist who expresses his anti-religious stance in a clearly visible manner by the way he dresses, or a politically active employee who professes his allegiance to his preferred political party or particular policies through the clothes that he wears (such as symbols, pins or slogans on his shirt, T-shirt or headwear). ${ }^{6}$ The Court followed this reasoning and ruled that all workers in the company were treated equally. Clearly, different beliefs - be they religious, political, or philosophical by nature - are here compared to each other. They are all equally prohibited. But the true comparison should be with the average employee who does not show his or her beliefs in a clearly visible manner in the workplace - in my opinion, still the majority of employees in Europe. As some commentators have pointed out: 'equal discrimination is still discrimination' ${ }^{7}$

3 Directive $2000 / 78$ art $2(2)(a)$.

4 See the opinion A-G Kokott and the case-law referred to there, 31 May 2016, C-157/15 Achbita $v G_{4} S$ Secure Solutions, Para 44.

5 C-157/15 Achbita v $\mathrm{G}_{4} S$ Secure Solutions [2017] CJEU, Para 44.

6 Opinion A-G Kokott, 31 May 2016, C-157/15 Achbita v G4S Secure Solutions [2016] CJE U, Para 52 and 53 .

7 S Ouald-Chaib and V David, 'European Court of Justice keeps the door to religious discrimination in the private workplace opened. The European Court of Human Rights could close it' (StrasbourgObserver)<https://strasbourgobservers.com/2017/03/27/european-court-of-justice 
The fact that the workplace policy in question also prohibits manifestation of political and philosophical beliefs does not change the inseparable link to religion. ${ }^{8}$

The decisive reason to treat this case differently from the previous case-law on direct discrimination seems for the Advocate General to be the fact that, as she points out herself, 'the previous cases were concerned with individuals' immutable physical features or personal characteristics - such as gender, age or sexual orientation - rather than with modes of conduct based on a subjective decision or conviction, such as the wearing or not of a head covering at issue here. ${ }^{9}$ The fact that it is a personal choice to wear a headscarf apparently carries a lot of weight in the decision-making. This reasoning downscales religion as part of personal identity and the right to practice one's religion as a fundamental right to a 'mode of conduct based on a subjective decision'. Moreover, the underlying EU-Directive does not differentiate in the grounds in this way. The Court does not mention this consideration in its judgments; in fact, it pays little attention to the freedom of religion. Some commentators see in this the biggest shortcoming of the judgments: the fact that a supranational court rules on fundamental rights in relation to the issue of Islamic headscarf bans 'without any reference to either the Europe-wide context of Islamophobia, or the widespread existence of negative stereotypes about Muslim women, and in particular those who wear Islamic dress.'10

The Advocate General Kokott does add to her opinion that if a ban such as this would prove to be based on stereotypes or prejudice in relation to religious beliefs, 'it would without any doubt be appropriate to assume the presence of direct discrimination based on religion'. However, the Court does not pay attention to this aspect and does not even request from the referring court to scrutinize whether the apparently neutrally formulated policy can in fact be disguised discrimination.

As said, the dismissal of Ms Bougnaoui was not based on the existence of an internal regulation such as in the Achbita case. She was dismissed after a

-keeps-the-door-to-religious-discrimination-in-the-private-workplace-opened-the-european-court-of-human-rights-could-close-it/> accessed 27 March 2017.

8 Moreover, the workplace rules in question were only enacted after Ms Achbita had informed her manager that she intended to wear an Islamic headscarf during working hours. The Court does not pay any attention to this fact.

9 Opinion A-G Kokott, 31 May 2016, C-157/15 Achbita v G4S Secure Solutions [2016] CJEU, Para 45.

10 E. Brems, 'Analysis: European Court of Justice Allows Bans on Religious Dress in the Workplace' (Blog of the IACL) <https://iacl-aidc-blog.org/2017/03/25/analysis-europeancourt-of-justice-allows-bans-on-religious-dress-in-the-workplace/> accessed 6 April 2017. 
customer had expressed the wish to no longer have services provided by a worker who, like Ms Bougnaoui, wears an Islamic headscarf. However, also here the CJEU does not qualify this as direct discrimination; it simply avoids that question. ${ }^{11}$ Instead, it concentrates on Article 4 sub 1 of the Directive $2000 / 78 / \mathrm{EC}$, as the referring court asked. This Article gives the Member States the possibility to provide that a difference of treatment does not constitute discrimination where, by reason of the nature of the particular occupational activities concerned or of the context in which they are carried out, the characteristics in question constitute 'a genuine and determining occupational requirement.' ${ }^{2}$ The Court finds that the concept of a 'genuine and determining occupational requirement' cannot cover subjective considerations, 'such as the willingness of the employer to take account of the particular wishes of the customer.13

\section{Freedom to Conduct a Business vs. Freedom of Religion and the Right to Work}

Even though the above ruling in the Bougnaoui case on Article 4 of the Directive is to be endorsed, the Court should have determined whether such a situation would constitute direct discrimination. Determining whether there is direct or indirect discrimination can make quite a difference. Indirect discrimination provides for more possible objectives that may justify a difference of treatment based on religion.

This brings us back to the Achbita case. The Court observes that it is to the referring court to ascertain whether the workplace regulation at issue constitutes indirect discrimination. However, it expresses that 'it is not inconceivable' that the referring court might indeed conclude that 'the apparently neutral obligation it encompasses results, in fact, in persons adhering to a particular religion or belief being put at a particular disadvantage.. ${ }^{14}$ Such a difference of treatment is, however, not prohibited if it is objectively justified by a legitimate aim and if the means of achieving that aim are appropriate and necessary. ${ }^{15}$ Whether this is the case is again up to the national court to decide, but the CJEU wishes to give guidance. It states that 'the desire to display, in relations with both public

\footnotetext{
11 Even though the A-G in this case found this to be direct discrimination, see the opinion of A-G Sharpston, 13 July 2016, C-188/15 Bougnaouiv Micropole SA [2016] CJEU, Para 88.

12 Provided that the objective is legitimate and the requirement is proportionate.

13 C-188/15 Bougnaouiv Micropole SA [2017] CJEU, Para 40 and 41.

14 C-157/15 Achbita v G4S Secure Solutions [2017] CJEU, Para 34.

15 Directive $2000 / 78$ art $2(2)(\mathrm{b})(\mathrm{i})$.
} 
and private sector customers, a policy of political, philosophical or religious neutrality must be considered legitimate. ${ }^{16}$ The Court seeks to give weight to an employer's wish to project an image of neutrality towards customers by linking it to 'the freedom to conduct a business' that is recognized in Article 16 of the EU Charter of Fundamental Rights.

When a legitimate aim has been identified, next in the 'proportionality test' is the question whether the means to achieve that aim are appropriate and necessary. The Court finds that the 'neutrality policy' in question is an appropriate means as long as this 'policy is genuinely pursued in a consistent and systematic manner.' ${ }^{17}$ Concerning the question whether the headscarf-ban was limited to what is strictly necessary, the Court observes that it is as long as the policy is only applied to employees who come into contact with customers. In this context, the Court further suggests for the national courts to take into consideration the question whether it would have been possible for the employer - without him being required to take on an additional burden - to offer Ms Achbita 'a post not involving any visual contact with those customers, instead of dismissing her'.18

The rulings have faced a lot of criticism. ${ }^{19}$ However, they have also received praise. Professor Buruma, a judge of the Dutch Supreme Court, argues that this 'reserved' ruling leaves room for national judges to take action against 'genuine' (indirect) discrimination. ${ }^{20} \mathrm{He}$ believes that a judge will not blindly accept an employer's seemingly neutral policy, but that he will examine the motives behind it. Through the 'indirect discrimination test' he can detect when an employer's true motive is to exclude certain people from employment. We are indeed now dependent on national (lower) courts to put these rulings in practice in a 'sensible way'. They may for example pay more attention to what type of business the company is conducting. In the Achbita case, it concerned a company that provides reception services for customers in both the public and

16 C-157/15 Achbitav G4S Secure Solutions [2017] CJE U, Para 37.

17 C-157/15 Achbitav $G_{4} S$ Secure Solutions [2017] CJEU, Para 40 and 41.

18 C-157/15 Achbita $v$ G4S Secure Solutions [2007] CJEU, Para 43.

19 Besides the already mentioned comments, see for example, E Spaventa, 'What is the point of minimum harmonization of fundamental rights? Some further reflections on the Achbita case' (EU Law Analysis) <http://eulawanalysis.blogspot.nl/2017/o3/what-is-point-ofminimum-harmonization.html> accessed 21 March 2017; G Davies, 'Achbita v G4S: Religious equality squeezed between profit and prejudice' (European Law Blog) <https:// europeanlawblog.eu/2017/04/o6/achbita-v-g4s-religious-equality-squeezed-betweenprofit-and-prejudice/> accessed 6 April 2017.

20 Y Buruma, 'Rechtspraak onder een populistisch gesternte' $($ NJBlog) $<$ http://njb.nl/blog/ rechtspraak-onder-een-populistisch-gesternte.22888.lynkx> accessed 3 April 2017. 
private sectors. It means the company sends their employees out to work for client companies. Arguably, a 'neutrality policy' is more appropriate for such a company than for example a regular retail shop. This would be an optimistic reading of the judgment, because the CJEU does not take such a nuanced stance, but rather generally states that 'the desire to display (...) a policy of political, philosophical or religious neutrality must be considered legitimate.'. Moreover, in these optimistic expectations the awareness is missing that discrimination and exclusion are not only results of some malign intentions. Discrimination can also result from patterns and practices of social exclusion and disadvantaging that do not necessarily need to be designed to promote discrimination. ${ }^{22}$

In addition, while in the Bougnaoui case the Court did not accept that a worker is dismissed because a customer has a problem with her appearance, in the Achbita case the Court undermines this consideration by allowing employers to put a 'neutrality policy' in place. The Court's rulings might in fact open the door for more expression of 'customers' discomfort' and prejudice with certain appearances and certain religions. These client companies may hereafter more often request a 'neutrality policy' from companies they do business with. They now know that it is legitimate to have such policies in place. ${ }^{23}$ Some commentators have gone as far as to argue that the CJEU has given private companies a blueprint for discriminating against Muslim women: 'introduce a neutrality policy that applies to all types of religious dress; apply it consistently; apply it only to front-office employees; and if you want to dismiss a person, make sure to motivate why you cannot offer that person a back-office job. ${ }^{24}$

The CJEU could have instead determined that private companies need to fully observe fundamental human rights as the right to equal treatment (Article 21 of the EU Charter), the freedom of religion (Article 10 of the EU Charter), and the right to engage in work and to pursue a freely chosen occupation (Article 15 of the EU Charter). This would create a level playing field, in the sense that all companies are obliged to comply. Employers with a diverse workforce could in

21 C-157/15 Achbitav G4S Secure Solutions [2007] CJEU, Para 37.

22 This is called systemic inequality; see for example: C Sheppard, Inclusive Equality (McGill-Queen's University Press 2010) 6.

23 Quite some newspapers have reported that the rulings mean a headscarf ban at the workplace is allowed. See for example, 'Europe's right hails EU court's workplace headscarf ban ruling' (The Guardian) <https://www.theguardian.com/law/2017/mar/14/employers-canban-staff-from-wearing-headscarves-european-court-rules $>$ accessed 14 March 2017.

24 E Brems, 'Analysis: European Court of Justice Allows Bans on Religious Dress in the Workplace' (Blog of the IACL) <https://iacl-aidc-blog.org/2017/03/25/analysis-european-courtof-justice-allows-bans-on-religious-dress-in-the-workplace/> accessed 14 March 2017. 
that case easily stand up to customers who have problems with certain groups of people, because they would not have to be afraid to lose these customers to companies that $d o$ have 'neutrality policies' and ban manifestations of religious, political or philosophical beliefs. After all, neutrality does not have to mean that everybody looks the same. As it has been mentioned before, also an 'inclusive' view of neutrality exists, one where neutrality means accepting manifestations of all religions on an equal footing. ${ }^{25}$

\section{$4 \quad$ Concluding Remarks}

Professor De Sousa Santos' central question is under which conditions law can be emancipatory. One of these conditions should be interculturality. The judgments by the CJEU that were discussed above, do not accommodate interculturality and diversity in Europe. This is a pity, because as the Advocate General Kokott pointed out, these cases are 'symbolic of the more fundamental question of how much difference and diversity an open and pluralistic European society must tolerate within its borders and, conversely, how much assimilation it is permitted to require from certain minorities. ${ }^{26}$ The implicit answer of the Court to this question would be that in Europe employers do not have to tolerate much difference and diversity in the workplace. Pursuing a certain corporate image can trump the rights of workers to express their beliefs and to work in an occupation of their choosing. The alternative for workers is to search for jobs where they are allowed to dress according to their conviction. However, it is not difficult to see how these rulings may diminish their chances on the labor market.

Projecting neutrality can be ground for rights restrictions when it is applied in the public sector. However, with these landmark rulings, this is expanded to the private sector, which only contributes to the growing power of the market over the state and the community.

\footnotetext{
25 Ibid.

26 Opinion of A-G Kokott 31 May 2016, C-157/15 Achbita v G4S Secure Solutions [2016] CJEU, Para 3.
} 